\title{
Post-traditional \\ Corporate Governance
}

\author{
Michael Mason and Joan O'Mahony \\ London School of Economics and Political Science, UK
}

Traditional definitions of corporate governance are narrow, focusing on legal relations between managers and shareholders. More recent definitions extend the boundaries of governance to consider the role that various stakeholders play in shaping the behaviour of firms. While stakeholder theory embraces a broader set of corporate constituencies, our argument in this paper is that even these definitions are too narrow - they lack the analytical capacity to account for the social embeddedness and legitimacy of corporate governance. More specifically, we argue that the spatial contexts of corporate governance are socially constitutive of their governance forms and effects. Different forms of corporate governance emerge in, and co-produce, variable operating contexts, as well as shape the roles and interests of their constituent actors. We distinguish between vertical and horizontal forms of governance in political and economic life, and outline several consequences for businesses of a shift to post-traditional corporate governance.

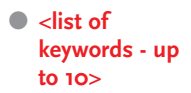

Dr Michael Mason is Deputy Director of the Centre for Environmental Policy and Governance at the London School of Economics and Political Science (LSE) and serves also as Director of the LSE/Alcoa Foundation Conservation and Sustainability Fellowship Programme. His major research interests are international environmental governance and corporate social responsibility.

Dr Joan O'Mahony is a research fellow at the Centre for Environmental Policy and Governance, LSE. Her research examines the different ways in which corporate activities are governed. As a member of CONNEX, a European Union-funded 'Network of Excellence', she has also developed the first online database on European governance.

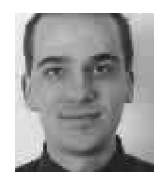

$\triangle$ Department of Geography and Environment, London School of Economics and Political Science, Houghton Street, London WC2A 2AE, UK

m.mason@lse.ac.uk

$<$ web address?>

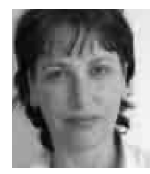

$\triangle$ Centre for Environmental Policy and Governance, London School of Economics and Political Science, Houghton Street, London WC2A 2AE, UK

j.omahony@Ise.ac.uk

$<$ web address?> 


\section{The rise of corporate governance}

THE MODERN CORPORATION CAME INTO EXISTENCE IN THE MID-19TH CENTURY when British legislation on joint stock incorporation and limited liability granted companies autonomous legal personhood. The notion of 'corporate governance' however is a more recent phenomenon, which is growing rapidly. The term first appeared in I98I in George Siedel's article, 'Corporate Governance under the Foreign Corrupt Practices Act' (Siedel I98I). In the following ten years, only a further I6 articles appeared on the subject. By 2002 there was a monumental rise in interest in the topic with I,085 articles written on the subject; the number of articles has doubled in the last four years. ${ }^{1}$ There is a clear coincidence in recent academic interest in corporate governance with the rise of laissez-faire policies and the rolling back of business regulation in many countries. Deregulation has substantially reduced the risks to any individual involved in setting up a corporation, but at the same time it has created a corresponding anxiety about the new and public risks that potentially result from the decline in national controls, and the risks associated with the spread of non-territorial capital. While the separation of ownership and control has always involved concerns about the concentration of power, and therefore its potential abuse, such concerns have taken on an added urgency in the face of conglomeration and the consequent substantive increases in the strength and scope of control that managers now possess, separated from their owners by everincreasing distances. But power differentials within companies are not the only cause for concern. The way has been paved for a proliferation of cross-territorial economic transactions where regulatory instruments that had been developed on the basis of a 'national economy' have become increasingly ineffective.

Possibly the most notable aspect of the OECD's (Organisation for Economic Cooperation and Development) definition of corporate governance is its widespread popularity. First appearing in 1999 (and then revised in 2004) it describes corporate governance as:

a set of relationships between a company's management, its board, its shareholders and other stakeholders [that] provides the structure through which the objectives of the company are set, and the means of attaining those objectives and monitoring performance are determined (OECD 2004: 13 ).

Many major international and national policy bodies (e.g. the World Bank, the European Commission, the UK Department for Business, Enterprise and Regulatory Reform) have adopted this definition. What appears at first glance to be a normatively neutral definition is, on further reading, one laced with directives as to the appropriate set of business relationships and goals. The goal of corporate governance is 'economic efficiency', the key corporate governance problems are those that 'result from the separation of ownership and control', stakeholders are those 'established by law' (investors, employees, creditors and suppliers), and the role of such stakeholders in corporate governance is recognised on the basis of their wealth-creating capacities. The European Commission recommends the OECD definition as 'comprehensive' (Commission of the European Communities 2003: I0) and also emphasises the key governance problem as that arising from the potentially diverging interests of managers and equity holders. Finally, the UK government describes the corporate governance relationship in similar narrow terms, as that 'between the constituent parts of a company-the directors, the boards and the shareholders' (Department for Business, Enterprise and Regulatory Reform 2007).

1 Numbers from the authors' count of the literature in the International Bibliography of the Social Sciences. 
These statements on corporate governance by leading policy-making bodies are directly reflected in the dominant academic school of thought on corporate governance-'agency theory' - which, for all its variations and nuances, ultimately sees corporate governance as 'a method to ensure that investors get themselves a return' (Mallin 2004: 5). Alternative definitions extend the boundaries of corporate governance to include the role that various stakeholders can play in shaping the behaviour of firms. However, while stakeholder theory embraces a broader set of corporate constituencies, these actors are still integrated into corporate governance arrangements on the basis of firms' contractual (employees, creditors, suppliers) or non-contractual obligations (affected communities, government, interest groups), and remain secondary to shareholder interests (Post et al. 2002; Friedman and Miles 2006).

In sum, the standard (one might even say, hegemonic) notion of corporate governance is one that takes the goal of corporate governance as the maximisation of shareholder value. The key actors are those of manager and shareholder, and the central problem is the principal-agent one; that is, the problem of how to ensure that the agent (manager) does in fact carry out the duties it is charged with, that of protecting the interests of the principal (shareholder). The great bulk of management and business articles have devoted themselves to discussing the various techniques that can best ensure that the agent's power is not abused and remains directed towards legitimate ends, the pursuit of which involves taking account of its broader legal obligations.

From a legal perspective, such a definition is scarcely objectionable. Though legal case history is replete with moments of ambiguity about the precise responsibilities of a corporate director, in general the courts have upheld the view that the overriding duty of managers is to maximise returns to shareholders. After Enron, legal revisions in the US and a series of legal committees in the UK have supported both the paramountcy of shareholder authority in corporate governance relations and the conventional goals of corporation governance legislation. Indeed, the UK Hempel and Turnbull Committees on Corporate Governance left no doubt that company directors are not accountable to other stakeholders. The OECD definition and the host of institutions and policy bodies that have adopted that definition are therefore providing corporations with a clear legal statement of what it is they are meant to be doing.

However, the legalistic concept formulated by the OECD is not an adequate one for social-scientific research, which aims not merely to describe, but also to explain the rise of corporate governance. Its definition does not provide for the fact that it is not law that determines solely what a corporation can or cannot do, nor law that has the power to determine the goals of corporations, or indeed to decide which actors are to be involved in the governance of corporations and the extent of their involvement. The shortcomings of this traditional concept of corporate governance can most readily be seen in the actual empirical activities of corporate directors. While the law assures managers that they need only have regard for the interests of their shareholders, reality demands otherwise. In his recent scholarly survey on corporate governance, Clarke (2004: I4) notes that 'managers are grappling with the need to satisfy the interests of many complex constituencies than shareholder theory would suggest'. Indeed, such a necessity to address broader social needs was long ago recognised by Durkheim in his famous discussion of contracts where he showed that, although the formation of a contract directly concerns only the parties involved, nonetheless, if a contract is to have binding force, it is society which confers that force through norms, values and customs (Durkheim, I9I $8<$ I984? $>$ ). In today's parlance, that force, with respect to the operation of corporations, is known as a 'social licence'. 


\section{Corporate governance and CSR: parallel worlds}

Precisely why an adequate analytical concept of corporate governance has failed to develop in recognition of both the contractual and the social forces that govern corporations is a topic worthy of investigation but one we cannot cover here. What we do want to suggest is that the lack of a more sociological concept of corporate governance has most readily been demonstrated by the emergence of the concept of corporate social responsibility (CSR), and indeed by the creation and growth of corporate citizenship studies as a separate disciplinary field. ${ }^{2}$ CSR discourse advances a concept of business responsibility at odds with traditional notions of corporate governance. Where the latter affirms that corporate legitimacy be judged on the basis of the capacities of a company to increase equity value - a capacity that is secured by the appropriate distribution of rights and responsibilities between shareholder, board and director-the concept of CSR sets out a broader notion of goals and of the means to attain them. Both views, narrow and broad, are recognised by the companies themselves. Thus, in their statement of General Business Principles, Shell declares that 'We commit to contribute to sustainable development. This requires balancing short- and long-term interests, and integrating economic, environmental and social considerations into business decision-making' (Royal Dutch Shell 2005: 4). Similarly, GlaxoSmithKline's CEO and Chairman write in their introduction to their company's report that 'while the interests of shareholders remain paramount we also need to respond to stakeholder expectations by helping to address society's healthcare challenges. We accept this challenge' (GlaxoSmithKline 2005). And Paul Myners (2006: 3), Marks \& Spencer's Chairman, writes in the 2006 report that 'we believe that being a responsible business is the right thing to do but we also believe that it makes good business sense'. Finally, despite the Hempel/Turnbull judgement that directors are not accountable to stakeholders, British American Tobacco states: 'We are working for wider accountability to society, and engaging in constructive dialogue with stakeholders on the issues surrounding our products....Today, perhaps more than ever, society expects businesses to use their economic strength for broader social goals' (British American Tobacco 2006).

In sum, the governance of the modern corporation is driven by a legal requirement demanding that corporate powers are distributed between the set of company's contractual actors (as laid out in the concept of corporate governance), and a social requirement that dictates that the power of corporations is greatly dependent on the legitimacy conferred by a much broader set of social forces (as laid out in the notion of CSR). Both concepts have developed apace, but they have done so largely divorced from one another, with corporate governance reports and corporate responsibility reports published separately by different departments within the same corporation.

\section{Towards integration? Post-traditional corporate governance}

Whatever the reasons for the emergence of CSR and the extent to which its emergence and proliferation can be attributed to the inadequacies of the corporate governance concept, there are, we suggest, consequences to keeping the two discourses apart. We claim that there are three major drawbacks arising from this separation.

First, modern corporations exhibit what we describe as a role neurosis. Two seemingly irreconcilable sets of responsibilities face the contemporary manager: at one

2 One of the reasons lies undoubtedly with the dominance of the subject area by management studies (on the relegation of corporate citizenship to a management issue, see Glazebrook 2005). 
moment compelled to present herself/himself as a governor, at the next as a citizen. Yet keeping such demands separate, both conceptually and in practice, contributes to the fact that the potential conflict in such a set of responsibilities is never recognised. Instead, the recognition of broad social goals is recommended as compatible with that of narrow shareholder interest. For example, the UK government simply states: 'The Government sees CSR as good for society and good for business' (UK Government 2006). And the European Commission's Directorate-General for Enterprise and Industry $<$ (date) ? > blithely maintains that CSR 'is about integrating social and environmental concerns into business strategy and operations' (Department for Business Enterprise and Regulatory Reform 2007). Nowhere, in the business or policy discourse is much credence given to the obstacles that such a project might entail.

Second, the insistence that social goals can be addressed unproblematically without reform of the current governance framework makes it difficult to assess what can be integrated and what cannot. What does integration actually mean here? And why is it presumed to preclude the possibility of trade-offs and disagreements? More precisely, the invitation to integrate with, rather than interrogate, business strategy belies the subordination of CSR to the current drivers of corporate governance. Above all, the sovereign authority of shareholders means that new norms of non-financial corporate responsibility are adopted (or not) on their terms - that is, they must be compatible with the maximisation of shareholder value: other things being equal, the integration of CSR concerns into corporate governance can be expected only when shareholders take a long-term, 'enlightened' view of their self-interest.

Third, the separation of corporate governance from CSR contributes to the diffuse utopianism often characterising the latter, seeking meaning detached from the everyday demands and practicalities of business. One aspect of this is the uncritical appropriation by many CSR advocates of other discourses of social responsibility: for example, that of citizenship. If the corporation is, as some commentators argue, 'a citizen', who then are the co-citizens? Are they just other companies? Are they actors with contractual relations to the corporation (e.g. employees, creditors, suppliers). What of constituencies significantly impacted by corporate behaviour (e.g. affected communities) but with no contractual links with the businesses in question? Are they, then, sub-citizens with weaker claims on corporations? There is clearly a problem in adopting citizenship roles too quickly, particularly when they threaten to dilute the clear rights, privileges and obligations that are conventionally ascribed to citizens as equal members of political communities (Glazebrook 2005; Thompson 2005).

It is for these reasons that we urge the development of a concept of post-traditional corporate governance. The integration of notions of social responsibility into the ways that companies are governed cannot possibly be met while two competing models insist on different goals. In contrast to the traditional model of corporate governance, a posttraditional concept of corporate governance needs to recognise that rule-making is bound by both the law and the social force of moral and ethical persuasion. And it cannot assume by fiat which actors are involved in governing the corporation and how they do so. Such actors change depending on political circumstance, and these contexts of operation are constitutive of their power. In other words, we need to break with the tradition of addressing corporate governance in isolation from wider patterns and processes of societal governance. 
Early social scientific scholarship on governance dwelt on new forms of decision-making taking place within domestic political systems. The innovation in governing was taken to be the inclusion of non-state actors, who engaged with the state in a variety of (sub)national roles, many of which distanced them from hierarchical centres of governmental power (Rhodes I996; van Kersbergen and van Waarden 2004). More recently, governance has served as a description of new modes of private and/or public authority extending beyond the nation-state, qualified as 'global' or 'transnational'. As at the national scale, we observe the systematic involvement of non-state actors but, in the absence of a world government, the reliance on 'non-hierarchical' structures of rulemaking and implementation is even more pronounced (Risse 2006). Uncomfortable with the division of governance space according to the national/global binary, some writers argue that the new geographies of governance are more accurately represented as multi-scalar or reticular (Bulkeley 2005).

Governance is thus implicated in the articulation and constitution of new scales or spaces of governance. In the literature, the key geographical distinction in the mapping of governance forms is whether they are taking place according to a territorial or functional differentiation of space. As we now outline, this has a pivotal bearing on how the norms and practices of corporate responsibility are delimited.

\section{Territorial differentiation of space}

The voluminous literature on globalisation has both informed, and been influenced by, observations on the rescaling of governance mechanisms. A recurrent theme is the extent to which territorial forms of state control are 'denationalised' or diluted by new global relations of public and private authority. Neoliberal conceptions of globalisation point to an unambiguous displacement of national authority by global market forces (Ohmae I995; Friedman 2005). In this 'hyperglobalist' scenario, governance is self-evidently market-led - the global standardisation and management of capitalist rules of trade and investment. The territorial scaling here is centrifugal, such that there is, it is claimed, a vertical or upwards shift in governing authority to international or supranational institutions invested with pooled sovereignty. This is more than a spatial realignment of public authority; national policy structures and mechanisms are transformed and disciplined by global economic demands. Not surprisingly, corporations-particularly transnational corporations - are perceived as drivers of the 'marketisation' of governance at the global scale. Good corporate governance in hyperglobalist discourse refers to the non-binding standards of transparency, which are often generalised within and/or between economic sectors as global norms of business responsibility. The scope for CSR rests on its compatibility with this market liberal (contractual) model of accountability in which only shareholders are legally empowered to scrutinise corporate decision-making.

Not all commentators on globalisation concede that new governance arrangements are associated with the simple erosion of state authority. In the first place, there is a claim for the continuing primacy of national governance structures and mechanisms: even transnational companies and global markets still depend on state authorities to protect commercial freedoms. And the fact that international trade and financial arrangements extend the role of international law actually reinforces, it is contended, the sovereign legal authority of nation-states (Hirst and Thompson I999). Second, there is the recognition that global economic and social dynamics are reconstituting assemblages of territory and authority, but that this has multiple scalar implications for gov- 
ernance. Against the cultural readings of globalisation that impute a sweeping 'deterritorialisation' (Appadurai I996) or 'supraterritorialisation' (Scholte 2000), we observe a more sophisticated positioning of governance systems. Thus, Brenner (2004) identifies an ongoing dialectic of deterritorialisation and reterritorialisation, prompted by global capitalist restructuring, in which state institutions are $<$ move? $>$ upwards, downwards and outwards to create new spaces for the deployment of governance authority. Wettstein (2005) and Sassen (2006) are more open still to context-specific instantiations of governance which follow complex development paths, blending-and transformingglobal and national logics: for example, currency and human rights regimes. In these conceptualisations, corporations — as private agents —operate in new institutional zones that retain some embedding in national contexts or regulatory control (both home country and host country).

\section{Functional differentiation of space}

Various commentators have argued that new governance structures and mechanisms actually represent a break from hierarchical (vertical) forms of authority; instead they are shaped by network (horizontal) modes of coordination (Kooiman I993; Leitner 2004). More generally, the characterisation of the global economy as organised around transnational networks of capital, management and information is at the heart of attempts to posit the emergence of a new network society (Castells I996). However, most conceptualisations of network governance do not embrace such a far-reaching social morphology: they identify, more modestly, particular institutional settings featuring private organisations or mixes of private and public ones. Governance networks are typically informal, deemed to rely above all on non-hierarchical or voluntary forms of steering. As their interaction space is reticular (network-based) rather than territorial, their rule-setting and implementation mirrors the contours of a particular problem or function rather than the pre-existing boundaries of national and international authority (Voss et al. 2006).

Corporations initiate and/or engage in a variety of such networks, differentiated by function and actor involvement. Those addressing CSR goals include environmental stewardship schemes, industry-wide benchmarking of social and ecological standards, and multi-stakeholder partnerships. A high-profile exemplar of this governance mode, discussed below, is the United Nations (UN) Global Compact-a forum for international corporate responsibility explicitly informed by a 'learning network' rationale: transnational corporations work directly with the UN, in partnership with civil society groups, in identifying and promoting 'good corporate practices' (Ruggie 2002; Kell 2003).

\section{Identifying the actors in post-traditional corporate governance}

Much of the enthusiasm and interest in CSR rests on these governance systems bringing a host of new actors into the corporate decision-making process. The problem with many of these discussions on corporate responsibility is that they concentrate on the type of actor involved (civil society or government) rather than the actor's function (function tends to be read off from type). We contend however that it is not 'who' is involved in corporate governance but rather 'what' is involved that is the central question. It is the powers of actors, how those powers are institutionalised, and how they vary that is central to the question of the meaningfulness of any particular governance configuration. In some corporate governance arrangements, government actors are firmly the key regulators, in others they are facilitators, while in others they are advocates. Further- 
more our interest in such actorhood needs to recognise that governance actors exist in synergistic relationships, where the powers of one actor will of course be constituted and affected by the powers of another. Precisely what those powers are will be affected to a great degree by the shape and location of governance forms.

From a methodological point of view another tendency in discussions about stakeholder involvement in corporate governance is that of some CSR practitioners/professionals to give the answer 'everybody' to the question of who to include in decision-making. Many of those promoting good corporate governance argue that anyone who has an impact or a potential impact on the corporation is a governance stakeholder. Indeed, there is a commonplace argument that sets out the business case for CSR by highlighting the reputational gains that arise from companies maximising instances of civic interaction - the more stakeholders the better, the more diverse the better (e.g. Fombrun et al. 2000). While such an inclusionary<inclusive? > approach to governance may be laudable, from an analytic viewpoint it is somewhat unhelpful in locating the differential interests of all those making claims for access to corporate governance. In this discussion we take corporate governance actors to mean those actors with an institutionalised role in, and/or significant influence on corporate decision-making.

To illustrate our argument on the constitution of post-traditional corporate governance within wider governance networks, we give two brief examples: the UN Global Compact and the European Commission's Civil Society Dialogue on trade.

\section{Global governance: the UN Global Compact}

As already mentioned, the UN Global Compact has been represented as a paradigmatic case of network governance. It has eschewed formal rule-making on corporate sustainability, instead eliciting commitments from companies to adhere to existing universal statements on core human rights, labour standards and principles of sustainable development. As a loosely structured 'social learning network', the Global Compact promotes a horizontal model of dialogue in which the Global Compact Office publicises and facilitates communication and coordination between participating companies and civil society actors. These information exchanges take place through a web-based learning forum, multi-stakeholder dialogues and regional Global Compact networks. In practice, the Compact is overwhelmingly composed of business organisations, who are the key partners. Civil society stakeholders have complained both of their marginalisation within the Global Compact and that the Global Compact Office itself has been deficient in its monitoring of the behaviour of participating companies. It is significant that this questioning of the integrity (and accountability) of the initiative has led to the Global Compact Office taking its oversight responsibilities more seriously, while strengthening the advisory role of environment and development NGO (non-governmental organisation) participants as distinct from participating business associations. In other words, there has been a realignment of the governance roles of participating actors in order to boost the legitimacy of the initiative.

\section{The European Commission and the Civil Society Dialogue on trade}

The 'Civil Society Dialogue' sponsored by the European Commission is a clear example of a governance network where the participants' roles are, to an extent, demarcated and institutionalised. It is also a model that exemplifies the merits of conceiving of network participants not purely in terms of role or sector status (business, civil or government), but also in terms of the variance in functions and powers that attach to each role position. Such functions and powers are constituted in a relational sense where alterations 
in one role will often see a corresponding adaptation or alteration in another role. Civil society, for example, may enter a network in a mere observational capacity but over time become constituted as an adviser, auditor or interlocuter. It is these changes and the corresponding shifts in power that need to be the focus of attention in examinations of governance networks.

The European Commission is the executive wing of the European Union and holds responsibility for initiating and implementing legislation. It is a governance body par excellence: its powers conferred through the cooperation of national governments (the European Union) but with no direct accountability to a national or supranational (European) electorate. Its perceived democratic deficit has triggered pressure on the Commission for greater transparency and accountability to citizens and civil society at the national and European level, including pressure from business associations unhappy with increasing regulatory demands.

The 'Civil Society Dialogue' in Directorate-General (DG) Trade was established in I998 and was one of the earliest attempts by the Commission to establish a structured dialogue with civil society. The dialogue brought together business and civic associations in a conscious effort to practise the Commission's policy of good governance and to give voice to all stakeholders. Prior to I998 informal consultations between DG Trade, experts and outside bodies took place, but it was not until the launch of the Civil Society Dialogue that an institutionalised place at the table was created for business and civic associations. Even then, however, dialogue initially proceeded on an ad hoc basis, with DG Trade organising the meetings and taking responsibility for the setting of the agenda. The collapse of trade negotiations at Seattle and the media coverage of NGO concerns was a major impetus to the Commission to structure more thoroughly a role for civic and business associations as joint members of a European civil society. Dialogue after I999 became more regular, more institutionalised. Where DG Trade had initially monopolised the role of 'organiser', a combination of business and civic associations came to forward the 'contact group' which took over the task of setting the agenda for discussions. This has had a significant impact on Commission deliberations on governance: indeed, the Commission's White Paper on Governance (Commission of the European Communities 200I) endorsed their recommendations for greater consultation with civic and business associations in EU decision-making.

These examples of governance networks (Global Compact and Civil Society Dialogue) illustrate different trajectories for business engagement with non-national governance networks, where the collective representation of corporate interests was, in one case, constituted as separate from civil society (Global Compact) and, in the other, part of civil society (Civil Society Dialogue). Both examples also highlight the autonomous, significant role of business associations in attempting to influence the rules of the game under which corporations operate. Transnational civil society forums connected to international or supranational organisations have acquired increasing weight in the global business environment, with power to confer or withdrawal social legitimacy on private economic actors. Precluded by their for-profit status from participating directly in civil society dialogue, corporations must look to their business associations to project their corporate governance/CSR interests within these arenas. In the Global Compact case, high-profile CSR commitments by participating corporations were rendered vulnerable by the initial lack of effective engagement by non-business civil society associations in its internal decision-making. In the case of DG Trade, business associations joined environment and development NGOs as 'social partners' in assuming increasing control of a civil society dialogue on trade that influenced wider European Commission policy proposals on European governance. To be sure, these same business associations were also active in other Commission consultative arenas (e.g. the European Corporate Gover- 
nance Forum), where their push for regulatory relief created more tension with environmental advocacy groups; so the strategic positioning of business associations vis-àvis civil society is context-dependent.

The renewal of a social licence? The effects on businesses of posttraditional corporate governance

The new forms of governance outlined above have significant consequences for the behaviour and control of corporations. Depending on the governance mechanism and purpose, the enthusiasm of businesses will vary: the declared preference of most large corporations for non-mandatory regimes of CSR monitoring and review reflects the voluntarist self-understanding of good governance prevalent within the private sector. Yet there is extensive evidence of new procedural opportunities for stakeholders in corporate governance, even if the legal entitlements are indirect (via social and environmental regulation) rather than embedded in company law. It is much more difficult to gauge the substantive changes in corporate performance (financial and non-financial) that may have arisen as a result of new forms of public and private governance. Aside from the analytical problem here of the absence of systematic empirical information and the presence of numerous intervening variables, there are unavoidable normative implications bound up with the evaluation of governance effects. It is useful nevertheless to set out discrete classes of governance effects that are associated with distinctive aspects of posttraditional corporate conduct and behaviour: transparency, stakeholder participation, organisational learning and accountability.

\section{Transparency}

Good corporate governance on CSR issues has become associated above all with managerial transparency and, insofar as firms are embracing the corporate citizenship agenda, an openness to the concerns of community stakeholders and environmentalists. The rapid growth of sustainability reporting is an important indicator of the diffusion within the global business world of norms of social and ecological responsibility (Association of Chartered Certified Accountants 2004; Owen 2006). In November 2006 , www.corporateregister.com (accessed I3 June 2008), the most comprehensive online directory of corporate non-financial reports, listed 12,709 reports from 3,467 companies across 88 countries. By itself, of course, this reveals nothing of the reasons corporations adopt such norms; but, in the wake of several high-profile corporate corruption cases, the growing uptake of voluntary sustainability reporting resonates with wider moves by state and non-state actors to strengthen public scrutiny of the financial and non-financial conduct of businesses.

\section{Stakeholder participation}

Arguably, the greatest potential challenge posed by CSR proponents to existing structures of corporate governance-one that rests on the outcome of shifting political coalitions and interests-is the legal empowerment of stakeholder interests, notably social and ecological communities significantly affected by corporate decisions. There are few signs of this at the level of national governments, where shareholders have been the targeted beneficiaries of more onerous legal rules on financial reporting and corporate transparency (e.g. 2002 Sarbanes-Oxley Act in the US). To be sure, some commentators have identified international moves to legally recognise stakeholder rights. For 
example, Thompson (2005) notes such a provision in the Principles of Corporate Governance prepared by the OECD (I999<2004? >), which he claims anticipates a transition from CSR to corporate citizenship, where stakeholders are legally represented in business boardrooms. Yet there is little prospect of a breakdown or even significant dilution in the tight legal control exerted on company directors by shareholders.

\section{Organisational learning}

While commentators have remarked on the lack of theoretical precision and clarity in the literature on organisational learning (e.g. Wang and Ahmed 2003), there is a general recognition that the transfer of knowledge and skills within and between companies may be enhanced by increased corporate transparency. However, the inward-looking, functionalist slant of much organisational learning literature has tended to miss the knowledge gains for corporations that may be available from increased communication with civic actors. Even in instrumental terms, there are obvious cognitive benefits (e.g. joint problem-solving, managing external risk exposure) to businesses from consulting stakeholders. Furthermore, recent anthropological perspectives on organisational learning are pinpointing more precisely the relationship between governance activity and knowledge transfer within and between corporations (Amin and Cohendet 2000, 2004<2005?>; Black 2006).

For example, Wal-Mart's 'sustainable value networks' have recently been lauded as intra-company learning with their institutionalisation of collaborative groups comprising executives, suppliers, environmental NGOs and public regulators (Gunther 2006). And Thompson (2005) observes that the 'internationalisation of voluntary standards' of corporate social and environmental reporting represents the leading edge of intercompany learning. Prominent examples here include the Global Reporting Initiative, the World Business Council for Sustainable Development and, again, the Global Compact (with its explicit 'social learning network' model as described in Ruggie 2002).

\section{Accountability}

Accountability effects (intended or unintended) are inevitable consequences of the growing tendency of corporations to adopt comprehensive systems for non-financial (social and environmental) responsibility. By accountability we mean, following Bovens (2006: 9): 'a relationship between an actor and a forum, in which the actor has an obligation to explain and to justify his or her conduct, the forum can pose questions and pass judgement, and the actor may face consequences'. Corporate governance initiatives oriented to CSR remain locked within the 'soft' accountability framework of market liberalism where, outside contractual relationships, answerability to affected social and ecological communities is solely at the discretion of the company. Perceived deficiencies with this model of responsibility have animated civil society actors to employ novel forms of governance control to put pressure on corporations for greater public answerability and redress: for example, civil regulation and the creative use of common law tort claims (Mason 2005; Vogel 2006). The scope of such accountability demands is unlikely to diminish as long as the negative social and environmental impacts of corporations are widely perceived by civil society actors as unchecked by state authorities.

Indeed, the growth of a global human rights discourse on corporate social and environmental performance is accentuating the demands for stronger (legal) modalities of corporate accountability within and across national borders. Proposals include calls to enshrine minimum standards of corporate public accountability for corporate behaviour in an international treaty framework: for example, procedural rights of affected communities to consultation and judicial review over corporate decisions (Dine 2000: 
I76-82) and the obligation on corporations to respect core human rights (United Nations Sub-Commission on the Promotion and Protection of Human Rights 2003; Wettstein 2005).

\section{Conclusion}

It is now accepted by many leading companies that 'good corporate governance' encompasses an inclusive, stakeholder-based approach. At least for UK and other European companies, this implies sensitivity to an operating environment in which CSR, human rights and environmental standards are routinely acknowledged, both in terms of social, ethical and environmental risk assessments and in terms of wider notions of appropriate corporate conduct (Ruggie 2006; Schepers 2006). Under this perspective, affected local communities join suppliers/contractors, employees and government regulators as legitimate stakeholders, but without any formal legal recognition. There is still a need for further comparative research to locate the motivations for this realignment of corporate governance; but it is clear that it would not exist were it not for the widespread belief among leading companies that 'good governance' is compatible with, and even a driver of, a long-term maximisation of shareholder value.

In this paper we have argued that even this 'enlightened stakeholder' approach misconstrues the social embeddedness of corporate governance. That embeddedness is manifest in the spatial contexts of corporate governance, which have real governance effects. Different forms of corporate governance emerge in, and co-produce, variable operating contexts, as well as shape the roles and interests of their constituent actors. We distinguished between vertical forms of governance where firms are governed by various (post)territorial articulations of state authority, and horizontal forms of governance where firms establish networks to govern their behaviour that are mainly voluntarist in nature. Whatever the motivations of participating companies, a material consequence of the dominant horizontal framing of corporate non-financial (social and environmental) responsibility is the dilution and displacement of social and political pressures for stronger vertical forms of accountability. For critics this means that CSR and corporate governance in general lack social legitimacy. The notion of post-traditional corporate governance offers a means of acknowledging business activity as embedded in wider networks of governing with a range of public and private actors: the simple recognition of this fact-including its unavoidable political role in shaping the social and environmental performance (both positive and negative) of corporations-is the first step in the necessary renewal of this social legitimacy.

\section{References}

Amin, A., and P. Cohendet (2000) 'Organizational Learning and Governance through Embedded Practices', Journal of Management and Governance 4.I-2: 93-II6.

— and P. Cohendet (2005) Architectures of Knowledge: Firms, Capabilities, Communities (Oxford, UK: Oxford University Press).

Appadurai, A. (1996) Modernity at Large: Cultural Dimensions of Globalisation (Minneapolis, MN: University of Minnesota Press).

Association of Chartered Certified Accountants (2004) Towards Transparency: Progress on Global Sustainability Reporting (London: ACCA).

Black, L.D. (2006) 'Corporate Social Responsibility as Capability', Journal of Corporate Citizenship 23: 2538. 
Bovens, M. (2006) 'Analysing and Assessing Public Accountability: A Conceptual Framework', European Governance Papers (EUROGOV) C-o6-oI (www.connex-network.org/eurogov/pdf/egp-connex-Co6-oI.pdf, accessed I2 April 2007).

Brenner, N. (2004) New State Spaces: Urban Governance and the Rescaling of Statehood (New York: Oxford University Press).

British American Tobacco (2006) 'What we believe', www.bat.co.uk/OneWeb/sites/uk_3mnfen.nsf/ vwPagesWebLive/939562FBi36BD60180256BF400033IDA?opendocument\&DTC=\&SID, accessed 28 February 2007.

Bulkeley, H. (2005) 'Reconfiguring Environmental Governance: Towards a Politics of Scales and Networks', Political Geography 24.8: 875-902.

Castells, M. (I996) The Rise of Network Society (Oxford, UK: Blackwell).

Clarke, T. (ed.) (2004) Theories of Corporate Governance (London: Routledge).

Commission of the European Communities (200I) European Governance: A White Paper (COM (200I) 428; Brussels: European Commission).

- (2003) Modernising Company Law and Enhancing Corporate Governance in the European Union: A Plan to Move Forward (COM (2003) 284; Brussels: European Commission).

Department for Business Enterprise and Regulatory Reform (2007) 'Better Business Framework: Corporate Governance’, www.dti.gov.uk/bbf/corp-governance/pageI5267.html, accessed I2 April 2007.

Dine, J. (2000) The Governance of Corporate Groups (Cambridge, UK: Cambridge University Press).

Durkheim, É. (I984[1918]<[1893]?>) The Division of Labour in Society (translated by W.D. Halls; Basingstoke, UK: Macmillan).

European Commission Directorate-General for Enterprise and Industry <date? $>$ 'Corporate Social Responsibility'; ec.europa.eu/enterprise/csr/index_en.htm, accessed 5 April 2007. < cited in text? remove? >

Fombrun, C.J., N.A. Gardberg and M.L. Barnett (2000) 'Opportunity Platforms and Safety Nets: Corporate Citizenship and Reputational Risk', Business and Society Review I05.I: 85-106.

Friedman, A.L., and S. Miles (2006) Stakeholders: Theory and Practice (New York: Oxford University Press).

Friedman, T. (2005) The World is Flat: A Brief History of the Twenty-first Century (New York: Farrar, Straus \& Giroux).

GlaxoSmithKline (2005) 'Corporate Responsibility Report', www.gsk.com/responsibility/cr_report_ 2005/ceo_statement.htm, accessed 28 March 2007.

Glazebrook, M. (2005) 'The Social Construction of Corporate Citizenship', Journal of Corporate Citizenship I7: 53-67.

Gunther, M. (2006) 'The Green Machine', Fortune I54-3: 34-42.

Hirst, P., and G. Thompson (I999) Globalization in Question (Cambridge, UK: Polity Press, 2nd edition).

Joseph, S. (2004) Corporations and Transnational Human Rights Litigation (Oxford, UK: Hart Publishing). $<$ not cited in text - remove? $>$

Kell, G. (2003) 'The Global Compact: Origins, Operations, Progress, Challenges', Journal of Corporate Citizenship II: 35-49.

Kooiman, J. (ed.) (I993) Modern Governance: New Government-Society Interactions (London: Sage).

Leitner, H. (2004) 'The Politics of Scale and Networks of Spatial Connectivity: Transnational Interurban Networks and the Rescaling of Political Governance in Europe', in E. Sheppard and R.B. McMaster (eds.), Scale and Geographic Inquiry (Oxford, UK: Blackwell): 236-55.

Mallin, C. (2004) Corporate Governance (Oxford, UK: Oxford University Press).

Marks \& Spencer (2006) Corporate Social Responsibility Report (London: Marks \& Spencer Group plc).

Mason, M. (2005) The New Accountability: Environmental Responsibility Across Borders (London: Earthscan).

OECD (Organisation for Economic Cooperation and Development) (2004) OECD Principles of Corporate Governance (Paris: OECD).

Ohmae, K. (I995) The End of the Nation State: The Rise of Regional Economies (London: Harper Collins).

Owen, D. (2006) 'Emerging Issues in Sustainability Reporting', Business Strategy and the Environment I5.4: 2I7-I8.

Post, J., L. Preston and S. Sachs (2002) Redefining the Corporation: Stakeholder Management and Organizational Wealth (Palo Alto, CA: Stanford Business Press).

Rhodes, R. (I996) 'The New Governance: Governing Without Government', Political Studies 44.4: 65267.

Risse, T. (2006) ‘Transnational Governance and Legitimacy', in A. Benz and I. Papadopoulos (eds.), Governance and Democracy: Comparing National, European and International Experiences (London: Routledge).

Royal Dutch Shell plc (2005) Shell General Business Principles (The Hague: Shell International Limited).

Ruggie, J.G. (2002) 'The Theory and Practice of Learning Networks: Corporate Social Responsibility and the Global Compact', Journal of Corporate Citizenship 5: 27-36. 
- (2006) Human Rights Policies and Management Practices of Fortune Global 500 Firms (New York: Office of the UN Global Compact).

Sassen, S. (2006) Territory, Authority, Rights: From Medieval to Global Assemblages (Princeton, NJ: Princeton University Press).

Schepers, H. (2006) 'The Changing Role of Corporate Governance: From Short-term Accountability to Long-term Sustainability-A Perspective from FTSE Ioo Companies' (unpublished manuscript available from authors).

Scholte, J.A. (2000) Globalization: A Critical Introduction (Basingstoke, UK: Macmillan).

Siedel, G.J. (I98I) 'Corporate Governance under the Foreign Corrupt Practices Act', Quarterly Review of Economics and Business 21.3: 43-48.

Thompson, G.F. (2005) 'Global Corporate Citizenship: What Does it Mean?' Competition and Change 9.2: 203-24.

UK Government (2006) 'The Business Case for CSR'; www.csr.gov.uk/businesscasecsr.shtml, accessed 5 April 2007.

United Nations Sub-Commission on the Promotion and Protection of Human Rights (2003) Commentary on the Norms on the Responsibilities of Transnational Corporations and Other Enterprises with Regard to Human Rights (UN Doc E/CN.4/Sub.2/2003038/Rev2; Geneva: UN Commission on Human Rights).

Van Kersbergen, K., and F. van Waarden (2004) “"Governance” as a Bridge between Disciplines: Crossdisciplinary Inspiration Regarding Shifts in Governance and Problems of Governability, Accountability and Legitimacy', European Journal of Political Research 43.2: I43-7I.

Vogel, D. (2006) The Market for Virtue: The Potential and Limits for Corporate Social Responsibility (Washington, DC: Brookings Institution Press).

Voss, J.P., D. Bauknecht and R. Kemp (eds.) (2006) Reflexive Governance for Sustainable Development (Cheltenham, UK: Edward Elgar).

Wang, C.L., and P.K. Ahmed (2003) 'Organizational Learning: A Critical Review', The Learning Organization IO.I: 8-I7.

Wettstein, F. (2005) 'From Causality to Capability', Journal of Corporate Citizenship I9: I05-I7. 